\title{
Effects of Planting Date and Spatial ArRangement on Common BEAN (Phaseolus vulgaris) YIELD UNDER WEED-FREE AND WEEDY CONDITIONS $^{1}$
}

\author{
Efeito da Época de Plantio e do Arranjo Espacial em Feijoeiro Comum (Phaseolus vulgaris) \\ com e Sem Infestação de Plantas Daninhas
}

ESMAEILZADEH, S. ${ }^{2}$, and AMINPANAH, H. ${ }^{2}$

\begin{abstract}
To evaluate the effect of planting date and spatial pattern on common bean yield under weed-free and weed-infested conditions, an experiment was conducted in Kelachay, Northern Iran, in 2013. The experimental design was a randomized complete block in a factorial arrangement with three replicates. Factors were planting date (10 August and 20 August), spatial pattern (square and rectangular planting pattern, with a planting distance of $30 \times 30 \mathrm{~cm}$ and $45 \times 20 \mathrm{~cm}$, respectively), and weed management regime (weed-free and weedy conditions, weeded and not weeded throughout the growing season, respectively). Results showed that the main effect of planting date was significant only for pod number per plant and seed number per pod. At the same time, pod number per plant, seed number per pod, pod length, and grain yield were influenced significantly by spatial pattern. Results of ANOVA have also indicated that all traits, except pod length, were influenced significantly by weed-management regimes. Moreover, effect of planting date and spatial pattern were nonsignificant for weed dry weight. Mean comparison has expressed a significant increment in seed yield for square planting arrangement $\left(1,055 \mathrm{~kg} \mathrm{ha}^{-1}\right)$ over rectangular $\left(971 \mathrm{~kg} \mathrm{ha}^{-1}\right)$. Weeding has also presented an overall $12 \%$ and $8 \%$ improvement in grain and pod yield over control (weedy check), respectively. Based on the results of this study, weed control, as well as square planting pattern, are recommended for obtaining the highest seed yield in common bean.
\end{abstract}

Keywords: common bean, competition, planting date, planting pattern, Phaseolus vulgaris.

RESUMO - Um experimento foi conduzido em 2013 em Kelachay, no norte do Irã, para avaliar o efeito da época de semeadura e do arranjo espacial na produtividade do feijoeiro com e sem infestação de plantas daninhas. O delineamento experimental foi de blocos casualizados, em esquema fatorial, com três repetições. Os fatores foram época de plantio (10 de agosto e 20 de agosto), arranjo espacial (sistema de plantio quadrado e retangular, com espaçamento de plantio de $30 \times 30 \mathrm{~cm}$ e $45 \times 20 \mathrm{~cm}$, respectivamente), e sistema de manejo de plantas daninhas (ausência e presença de plantas daninhas, com ou sem roçada durante todo o periodo de crescimento, respectivamente). Os resultados mostraram que o principal efeito da época de semeadura foi significativa apenas para número de vagens por planta e número de sementes por vagem. Ao mesmo tempo, número de vagens por planta, número de sementes porvagem, comprimento de vagem e produtividade de grãos sofreram influência significativa do padrão espacial. Os resultados de análise de variância indicaram também que todas as caracteristicas, exceto comprimento de vagem, sofreram influência significativa dos sistemas de manejo de plantas daninhas. Além disso, o efeito da época de plantio e do padrão espacial foram nãosignificativa para massa seca de plantas daninhas. A comparação das médias indicou um aumento significativo na produtividade de sementes no sistema de plantio quadrado (1.055 $\left.\mathrm{kg} \mathrm{ha}^{-1}\right) \mathrm{em}^{-}$ comparação ao retangular (971 $\left.\mathrm{kg} \mathrm{ha}^{-1}\right)$. A roçada de ervas daninhas também indicou um aumento geral de $12 \%$ e $8 \%$ no rendimento de grãos e vagem em comparação ao controle, respectivamente. Com base nos resultados deste estudo, recomenda-se o controle de plantas daninhas, bem como o sistema de plantio quadrado, para a obtenção de maior rendimento de sementes de feijoeiro comum.

Palavras-chave: feijoeiro comum, competição, época de plantio, sistema de plantio, Phaseolus vulgaris.

Recebido para publicação em 25.6.2015 e aprovado em 25.6.2015.

Rasht Branch, Islamic Azad University, Rasht, Iran. <haminpanah@yahoo.com>, <aminpanah@iaurasht.ac.ir >.

Planta Daninha, Viçosa-MG, v. 33, n. 3, p. 425-432, 2015 


\section{INTRODUCTION}

Grain legumes, as a protein-rich food, play an important role in human nutrition, especially in developing countries. Alone, they contribute up to $33 \%$ of the dietary protein needs of humans (Vance et al., 2002). Common bean (Phaseolus vulgaris) is a warmseason annual legume crop grown primarily for its protein and energy-rich dry seeds. Bean grains are a good source of iron and zinc (Buruchara et al., 2011) and have a low glycemic index (Widers, 2006). Worldwide, an estimated 23.1 million tons of common bean is produced annually on about 8.7 million hectares (FAO, 2014). In 2013, common bean was planted on 98,000 hectares in Iran, with a total production of almost 253,000 tons (FAO, 2014). In Northern Iran, common bean is cultivated in early May and harvested in early July. Moreover, after rice harvesting in August, this crop is cultivated in rice fields with good drainage, and harvested in midNovember.

Weeds are one of the major biological constraints in crop production and, therefore, their control is an important component of any crop production system. Common bean plants are sensitive to weed competition, mainly during the early vegetative growth stages (Blackshaw, 1991). Pynenburg et al. (2011) found that seed yield in dry bean (Phaseolus vulgaris) was reduced up to $85 \%$ as a result of season-long weed competition. Chemical weed control is still the predominant component of weed management in crop production. However, the excessive use of herbicides has already led to serious problems such as environmental pollution and evolution of resistance to herbicides in weed species (Rao et al., 2007). These problems highlighted the need for integrated weed management (IWM) programs (Hill et al., 1994). Manipulation in agronomic practices, such as planting date and planting pattern, may increase crop competitiveness against weeds. Planting date is one of the most important cultural practices for the success of common bean production in Northern Iran, especially when the crop is sown in August. Early planting of common bean can enable the crop to set and fill grain before the onset of late-fall chilling. Early planting can also provide the potential for producing a larger crop canopy earlier in the growing season, which can better utilize solar radiation for photosynthesis (De Bruin et al., 2010). Moreover, early planting can increase crop competitiveness against weeds, especially against late-emerging ones. However, very early planting of common bean exposes the germinating seeds to dry and warm conditions and, therefore, it has the potential to reduce stands and to cause uneven seedling emergence. Combining uneven seedling emergence and lower populations under these conditions may cause greater yield reductions. In contrast, late planting date causes the reproductive growth stage of the crop to face the fall chilling, which ultimately lowers yield. Unfortunately, the sensitivity of common bean to low temperature (Badowiec $\&$ Weidner, 2014) may be troublesome in temperate climate regions where the transitional drops of temperature occur frequently during late growing season (Figure 2). Srinivasan et al. (1999) reported yield reduction in chickpea due to chilling stress during the reproductive stage in high latitudes and hilly areas of Asia. Several studies have reported that planting date had a significant effect on crop growth and yield (Darby \& Lauer, 2002; Hossain et al., 2003; Bhardwaj et al., 2004; Schwarte et al., 2005).

Crop spatial pattern is another agronomic factor that can affect grain yield and crop competitiveness against weeds (Olsen et al., 2012). It has been suggested that uniform planting pattern increases the spatial uniformity in leaf area index (LAI), reduces mutual shading, and hastens canopy closure, all of which result in increased radiation interception (RI) by the canopy (Olsen \& Weiner, 2007) and increased crop growth and yield (Mashingaidze et al., 2009). At the same time, an equidistant spacing of crop plants may reduce light penetration or affect light quality (or both) under the crop canopy. This may restrict seed germination of some weed species, suppress weed seedling growth, and reduce seed production by weed plants (Mashingaidze et al., 2009). In a uniform pattern, intra-specific competition within the crop is delayed, while inter-specific competition with weeds begins sooner. This allows the crop population to shade and suppress the weeds (Weiner et al., 2010). 
Some researchers (Weiner et al., 2001; Olsen \& Weiner, 2005; Olsen et al., 2012; Dusabumuremyi et al., 2014) noted that increased crop uniformity had a negative effect on weed biomass. However, some other researchers (Teasdale, 1995; Westgate et al., 1997) reported that crop growth and yield does not always increase in narrow-row planting. Weiner et al. (2001) reported that the advantage of uniform planting pattern occurs only when weeds are present, while in their absence or when they are well controlled, uniform planting pattern may have no superiority over row planting pattern. Fanadzo et al. (2007) reported that under low water and nutrient supply, maize grain yield reduced with a reduce in row spacing, which was attributed to increased intra-specific competition for water and nutrients. This study aimed to evaluate the effects of planting date and spatial pattern on common bean growth and yield under weedfree and weed-infested plots.

\section{MATERIALS AND METHODS}

\section{Experimental site and design}

This experiment was conducted in Kelachay, Northern Iran, in 2013. Weekly precipitation and temperature during the growing period of common bean were presented in Figures 1 and 2, respectively. Table 1 presents some soil properties of the experimental field. The experimental treatments were arranged in a randomized complete block design with three replicates. This consisted of a factorial combination of two planting dates (10 August and 20 August), two spatial arrangements (square and rectangular planting pattern, with a planting distance of $30 \times 30 \mathrm{~cm}$ and $45 \times 20 \mathrm{~cm}$, respectively) and two weed management regimes (weed-free and weedy conditions, weeded and not weeded throughout the growing season, respectively). Each plot consisted of six 5-meter long rows

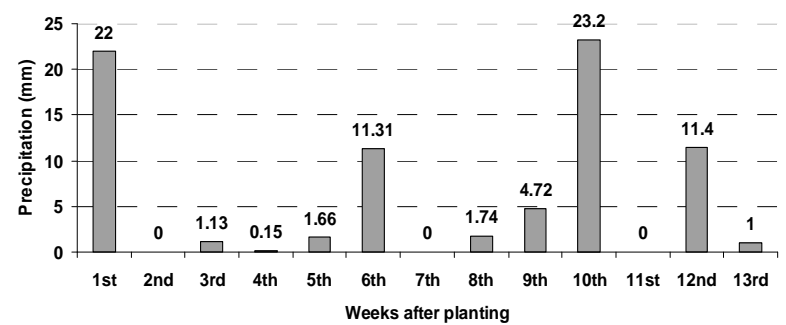

Figure 1 - Weekly precipitation during common bean growing period.

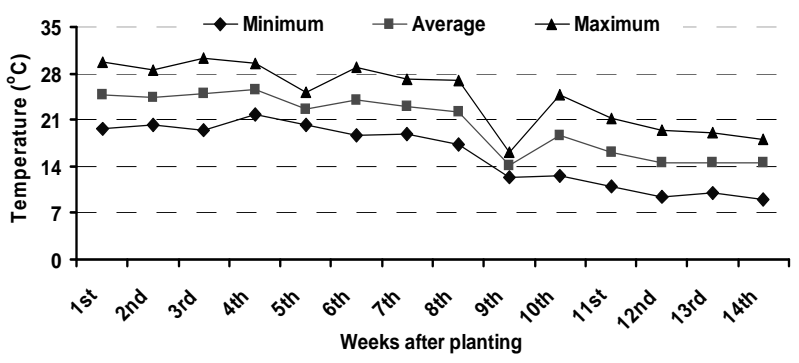

Figure 2 - Weekly temperatures (maximum, minimum and average) during common bean growing period.

separated from the neighboring plot by one empty row.

\section{Crop management}

Cultivation was started in August by preparing the soil with two perpendicular passes of disk harrow. Just before final land preparation, $\mathrm{N}, \mathrm{P}$ and $\mathrm{K}$ fertilizers were applied to the plots as recommended doses; i.e., $15 \mathrm{~kg} \mathrm{~N} \mathrm{ha}^{-1}$ (as starter in the form of urea), $50 \mathrm{~kg} \mathrm{~K}_{2} \mathrm{O} \mathrm{ha}^{-1}$ (as potassium sulphate), and $100 \mathrm{~kg} \mathrm{ha}^{-1} \mathrm{P}_{2} \mathrm{O}_{5}$ as triple super phosphate. Weed seedlings were removed manually just before seed planting. Plants were seeded on 10 and 20 August. To avoid water stress, the plots were irrigated as required. In weedfree plots, manual weeding was performed throughout the growing season. Since pests or diseases did not affect the crop, no pesticide was used during the experiment.

Table 1 - Some soil properties $(0-30 \mathrm{~cm})$ of the experimental field prior to sowing

\begin{tabular}{|c|c|c|c|c|c|c|}
\hline OC $(\%)$ & $\mathrm{pH}$ & Texture & $\left.\mathrm{EC}(\mathrm{ds} \mathrm{m})^{-1}\right)$ & Total N (\%) & $\mathrm{P}_{\left(\mathrm{mg} \mathrm{kg}^{-1}\right)}$ & ${\mathrm{K}\left(\mathrm{mg} \mathrm{kg}^{-1}\right)}$ \\
\hline 4.21 & 6.9 & loam & 0.46 & 0.35 & 35.2 & 198.2 \\
\hline
\end{tabular}

OC, Organic Content; pH, potential of Hydrogen; EC, Electrical Conductivity; N, Nitrogen; P, Phosphorus; K, Potassium. 


\section{Crop measurements}

Plants from planting dates of 10 and 20 August were harvested on 11 November and 3 December, respectively. At maturity stage, yield components, viz. number of pod per plant, number of seeds per pod, and 100-seed weight were determined on a randomly selected subsample of five plants (Malik et al., 1993). Green pods were harvested from the plants grown in half portion of each plot. The rest half of the crop of each plot was kept to allow the pods to get maturity and then the matured pods were harvested, hand threshed, and weighed. Seed yield was adjusted to $16 \%$ seed moisture content. To minimize the border effect, all samplings in each plot were done only on four central rows of $4 \mathrm{~m}$ (leaving two border rows and $0.5 \mathrm{~m}$ at the beginning and at the end of each row).

\section{Weed measurement}

Biomass of the weeds was determined by collecting the above ground portion of the weeds from four randomly selected 50 x $50 \mathrm{~cm}$ quadrates within each weedy plot at maturity stage, dried at $70^{\circ} \mathrm{C}$ for 3 days, and weighed in gram. Then, it was expressed as the weed dry weight per $\mathrm{m}^{2}$.

\section{Statistical Analyses}

Data were subjected to analysis of variance (ANOVA) using PROC GLM in SAS (SAS, 2004). Means were compared at the 5\% level of significance using Fisher's protected least significant difference (LSD). When the interaction among factors was significant (for seed number per plant, 100-seed weight and pod length), means for the interaction effects (with standard error) were compared, but when the interactions were not significant (pod number per plant, pod and seed yield), means for main effects were presented.

\section{RESULT AND DISCUSSION}

\section{Weed biomass and composition of weed communities}

The most dominant weed species in the experimental field were Amaranthus retofelexus, Setaria viridis, Datura stramonicum, Chenopodium album, Echinochloa crus-galli, Portulaca oleracea, Paspalum dilatatum, Cynodon dactylon and Cyperus esculentus ANOVA indicated that the main effect of spatial arrangement was significant for weed biomass, while the main effect of planting date and the interaction between spatial arrangement and planting date were not significant (Table 2). Weed biomass was 266.4 and $254 \mathrm{~g} \mathrm{~m}^{-2}$ for planting dates of 10 and 20 August, respectively. Weed biomass was significantly higher in the rectangular planting pattern $\left(288.2 \mathrm{~g} \mathrm{~m}^{-2}\right)$ than in the square planting pattern $\left(232.2 \mathrm{~g} \mathrm{~m}^{-2}\right)$. This result agrees with those reported by Holmes \& Sprague (2013), Acciares \& Zuluaga (2006), and Blackshaw et al. (1999), who found that narrowrow square planting pattern suppressed weed growth more effectively than wide-row planting pattern in beans. Moreover, Mashingaidze et al. (2009) reported that narrow rows in corn fields reduce biomass and seed production of weeds.

Table 2 - Mean squares of ANOVA for weed biomass as affected by planting date (D) and spatial arrangement (S)

\begin{tabular}{|l|c|c|}
\hline \multicolumn{1}{|c|}{ Source of variance } & Df & Weed biomass \\
\hline $\mathrm{R}$ & 2 & $582.2^{\mathrm{ns}}$ \\
\hline Planting date (D) & 1 & $463.2^{\mathrm{ns}}$ \\
\hline Spatial pattern (S) & 1 & $9408.0^{* *}$ \\
\hline D x S & 1 & $1.0^{\mathrm{ns}}$ \\
\hline Error & 14 & 891.4 \\
\hline CV (\%) & - & 11.5 \\
\hline
\end{tabular}

*, ** represent significance at 0.05 and 0.01 probability levels, respectively. ${ }^{\text {ns }}$ represents no significant difference.

\section{Pod and seed yield}

The main effect of weed management regime was significant ( $\mathrm{p} \leq 0.01$ ) for pod yield, while the main effects of planting date and spatial arrangement were not significant. Moreover, all two- and three-way interaction effects were non-significant (Table 3). Regardless of planting date and spatial arrangement, pod yield was reduced by $7.6 \%$ due to weed competition (Table 4). Seed yield was affected significantly only by weed management regime and spatial arrangement 
Table 3 - Mean squares of ANOVA for pod number per plant (PN), seed number per plant (SN), 100-seed weight (100-SW), pod length (PL), pod yield (PY), and seed yield (SY) as affected by planting date (D), spatial arrangement (S), and weed management regime $(\mathrm{W})$

\begin{tabular}{|c|c|c|c|c|c|c|c|}
\hline Source of variance & $\mathrm{df}$ & PN & $\mathrm{SN}$ & Thgw & PL & PY & SY \\
\hline $\mathrm{R}$ & 2 & $0.27^{\mathrm{ns}}$ & $0.003^{\mathrm{ns}}$ & $3.706^{\mathrm{ns}}$ & $3.60 *$ & $34948.7^{\mathrm{ns}}$ & $20362.1^{\mathrm{ns}}$ \\
\hline Planting date (D) & 1 & $20.35 * *$ & $0.032^{\mathrm{ns}}$ & $0.003^{\mathrm{ns}}$ & $2.28^{\mathrm{ns}}$ & $1552.0^{\mathrm{ns}}$ & $4760.1^{\mathrm{ns}}$ \\
\hline Spatial pattern (S) & 1 & $2.47 * *$ & $0.163 * *$ & $1.760^{\mathrm{ns}}$ & $19.98 * *$ & $18760.0^{\mathrm{ns}}$ & $42168.1 *$ \\
\hline Weed management regime (W) & 1 & $2.83 * *$ & $0.123 * *$ & $83.2 * *$ & $1.50^{\mathrm{ns}}$ & $140607.0 * *$ & $57624.0 * *$ \\
\hline $\mathrm{D} \times \mathrm{S}$ & 1 & $0.40^{\mathrm{ns}}$ & $0.025 *$ & $93.2 * *$ & $8.28 * *$ & 14065.0ns & $170.6^{\mathrm{ns}}$ \\
\hline $\mathrm{D} \times \mathrm{W}$ & 1 & $0.22^{\mathrm{ns}}$ & $0.564 * *$ & $15.2^{\mathrm{ns}}$ & $0.08^{\mathrm{ns}}$ & $273.3^{\mathrm{ns}}$ & $5104.1^{\mathrm{ns}}$ \\
\hline $\mathrm{S} \times \mathrm{W}$ & 1 & $0.30^{\mathrm{ns}}$ & $0.728 * *$ & $18.9^{\mathrm{ns}}$ & $1.08^{\mathrm{ns}}$ & $4959.3^{\mathrm{ns}}$ & $480.1^{\mathrm{ns}}$ \\
\hline$S \times D \times W$ & 1 & $0.51^{\mathrm{ns}}$ & $1.050 * *$ & $3.3^{\mathrm{ns}}$ & $0.22^{\mathrm{ns}}$ & $29051.0^{\mathrm{ns}}$ & $4615.5^{\mathrm{ns}}$ \\
\hline Error & 14 & 0.15 & 0.004 & 9.3 & 1.71 & 14002.1 & 7490.6 \\
\hline CV (\%) & - & 5.1 & 3.2 & 5.5 & 11.3 & 9.8 & 8.9 \\
\hline
\end{tabular}

$*, * *$ represent significance at 0.05 and 0.01 probability level, respectively. ${ }^{\mathrm{ns}}$ represents no significant difference.

Table 4 - Pod number per plant (PN), seed number per plant (SN), 100-seed weight (SW), pod length (PL), pod yield (PY), and seed yield (SY) as affected by planting date, spatial arrangement and weed management regime

\begin{tabular}{|c|c|c|c|c|c|c|}
\hline \multirow{2}{*}{ Trait } & \multicolumn{6}{|c|}{ Factor } \\
\hline & PN & $\mathrm{SN}$ & 100-SW & PL & PY & SY \\
\hline \multicolumn{7}{|l|}{ Planting date } \\
\hline 10 August & $6.7 \mathrm{a}$ & $2.8 \mathrm{a}$ & $54.9 \mathrm{a}$ & $11.2 \mathrm{a}$ & $1214.0 \mathrm{a}$ & $1027.0 \mathrm{a}$ \\
\hline 20 August & $8.5 b$ & $2.9 a$ & $54.9 \mathrm{a}$ & $11.9 \mathrm{a}$ & $1198.0 \mathrm{a}$ & $999.0 \mathrm{a}$ \\
\hline $\operatorname{LSD}(\mathrm{P} \leq 0.05)$ & 0.3 & 0.2 & $2 . .6$ & 1.1 & 103.0 & 79.0 \\
\hline \multicolumn{7}{|l|}{ Spatial arrangement } \\
\hline Square planting pattern & 7.9a & $3.1 \mathrm{a}$ & $55.2 \mathrm{a}$ & $12.5 \mathrm{a}$ & $1234.0 \mathrm{a}$ & $1055.0 \mathrm{a}$ \\
\hline Rectangular planting pattern & $7.3 \mathrm{~b}$ & $2.6 b$ & $54.7 \mathrm{a}$ & $10.6 \mathrm{~b}$ & $1178.0 \mathrm{a}$ & 971.0b \\
\hline $\operatorname{LSD}(\mathrm{P} \leq 0.05)$ & 0.3 & 0.2 & 2.6 & 1.1 & 103.0 & 79.0 \\
\hline \multicolumn{7}{|l|}{ Weed management regime } \\
\hline Weed-free & $7.9 a$ & $3.0 \mathrm{a}$ & $56.8 \mathrm{a}$ & $11.8 \mathrm{a}$ & 1283.0a & $1062.0 \mathrm{a}$ \\
\hline Weedy & $7.2 \mathrm{~b}$ & $2.8 \mathrm{~b}$ & $53.1 \mathrm{~b}$ & $11.3 \mathrm{a}$ & $1130.0 \mathrm{~b}$ & $964.0 \mathrm{~b}$ \\
\hline $\operatorname{LSD}(\mathrm{P} \leq 0.05)$ & 0.3 & 0.1 & 2.6 & 1.1 & 103.0 & 79.0 \\
\hline
\end{tabular}

Means followed by the same letter within a column among planting date, spatial arrangement or weed management regime are not significantly different according to Fisher's protected LSD ( $\mathrm{P} \leq 0.05)$.

at 0.01 and 0.05 probability levels, respectively (Table 3). Regardless of planting date and weed management regime, the plants produced more seed yield in uniform planting pattern compared to rectangular planting pattern (Table 4). Similarly, Dusabumuremyi et al. (2014) reported that bean yield was influenced significantly by planting pattern. They found that bean yield was reduced significantly by $22 \%$ in wide-row planting pattern compared to narrow-square planting pattern. They noted that narrow rows increase the evenness of
LAI distribution, reduce mutual shading, and shorten the time taken by the canopy to achieve full ground cover. These increase radiation interception by the canopy during the season and enhance crop growth and seed yield. Moreover, Acciaresi \& Chidichimo (2007) reported that reduced intra-specific competition (for water, mineral nutrients, and radiation) in the square planting pattern increased bean growth and yield. Seed yield was significantly greater in weed-free plots compared to weedy plots as averaged across 
planting date and spatial arrangement. The reduction in seed yield in the presence of weeds can be attributed to inter-specific competition between crop and weeds for light, water, and nutrient elements. Aguyoh \& Masiunas (2003) reported that snap bean yield was reduced by $13 \%-58 \%$ at densities $0.5-8$ of redroot pigweed plants per meter, respectively. Vogt et al. (2013) reported that the losses of grain yield in black common bean genotypes due to weed interference ranged from $30.8 \%$ to $54.9 \%$.

\section{Pod number per plant}

ANOVA indicated that the main effects of planting date, spatial arrangement, and weed management regime were significant for pod number per plant, but all two- and threeway interaction effects were not significant (Table 3). Regardless of spatial arrangement and weed management regime, pod number per plant increased by $26 \%$ as planting date went from 10 to 20 August (Table 4). Plants in uniform planting pattern produced higher pods compared to those in rectangular planting pattern as averaged across planting date and weed management regime (Table 4). This result is consistent with the result of Dusabumuremyi et al. (2014), who reported that number of pods per plant was higher in the narrow-row planting pattern than in the wide-row planting pattern. Regardless of planting date and spatial arrangement, pod number per plant was significantly higher under weed-free condition compared to weedy condition (Table 4). Pod number per plant reduced by $10 \%$ due to weed interference. Similarly, Malik et al. (1993) reported that season-long weed competition significantly reduced pod number per plant in white bean (Phaseolus vulgaris). Woolley et al. (1993) noted that in bean plants, pod number was the most sensitive yield component to weed competition.

\section{Seed number per pod}

Seed number per pod was not influenced significantly by planting date, while the main effects of spatial arrangement and weed management regime, and all two- and threeway interaction effects were significant (Table 3). This is contrary to the findings of
Dusabumuremyi et al. (2014), who found that seed number per pod was not influenced significantly by planting pattern. The highest seed number per pod was observed for plants seeded on 20 August in square planting pattern under weed-free condition, while the lowest one was recorded for plots seeded on 20 August in rectangular planting pattern under weedy condition (Table 5). Seed number per pod was significantly lower for plants grown under weedy condition compared to those grown under weed-free condition (Table 4). This finding is consistent with that of Malik et al. (1993) for white bean, who reported that seed number per plant was reduced significantly by weed competition.

Table 5 - Effect of spatial arrangement $\times$ planting date $\times$ weed management regime interaction on seed number per pod

\begin{tabular}{|c|l|c|c|}
\hline \multirow{2}{*}{$\begin{array}{c}\text { Planting } \\
\text { pattern }\end{array}$} & \multirow{2}{*}{$\begin{array}{c}\text { Planting } \\
\text { date }\end{array}$} & \multicolumn{2}{|c|}{ Weed management regime } \\
\cline { 3 - 4 } & Weed-free & Weed-infested \\
\hline \multirow{2}{*}{ 10-Aug } & Square & $3.1 \pm 0.04$ & $2.8 \pm 0.04$ \\
\cline { 2 - 4 } & Rectangular & $2.8 \pm 0.02$ & $2.7 \pm 0.01$ \\
\hline \multirow{2}{*}{ 20-Aug } & Square & $3.6 \pm 0.06$ & $2.7 \pm 0.02$ \\
\cline { 2 - 4 } & Rectangular & $3.0 \pm 0.04$ & $2.4 \pm 0.02$ \\
\hline
\end{tabular}

\section{Hundred seed weight}

Weed management regime and spatial arrangement $\times$ planting date interaction had significant effect on 100-seed weight (Table 3). Weed competition reduced significantly 100 -seed weight by $6.5 \%$ as averaged across planting date and spatial arrangement (Table 4). Malik et al. (1993) also reported the reduction in 100-seed weight under weedinfested condition for white bean. When plants were seeded on 10 August, 100-seed weight was significantly higher in rectangular planting pattern compared to uniform planting pattern. In contrast, when plants were seeded on 20 August, plants in uniform planting pattern had significantly higher 100-seed weight compared to those in rectangular planting pattern (Figure 3). Dusabumuremyi et al. (2014) reported that there was no significant difference in 1000-seed weight between square and wide-row planting patterns. 


\section{Pod length}

Spatial arrangement and spatial arrangement $\mathrm{x}$ planting date interaction had significant effect on pod length. Other main effects, two- and three-way interaction effects, were not significant for pod length. Regardless of planting date and weed management regime, significantly greater pod length was recorded in plots with the uniform planting pattern $(12.5 \mathrm{~cm})$ compared with the plots with the wide-row planting pattern $(10.6 \mathrm{~cm})$. When plants were seeded on 10 August, pod length was significantly greater in the uniform planting pattern compared to the wide-row planting pattern. In contrast, there was no significant difference in pod length between uniform and wide-row planting patterns for plants seeded on 20 August (Figure 4). Akter et al. (2013) reported that pod length in mung bean (Vigna radiata) was reduced significantly due to weed interference.

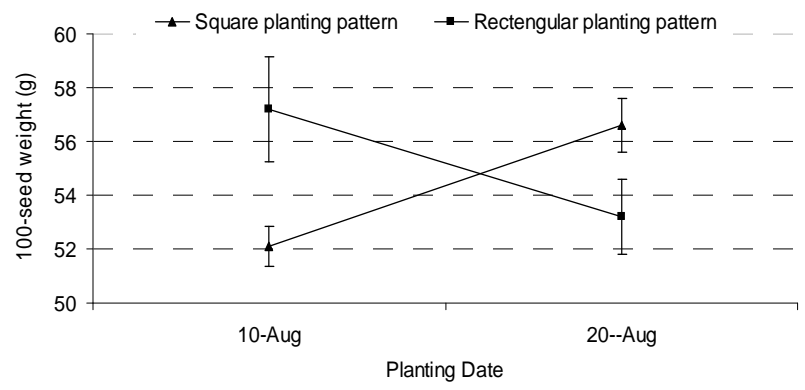

Figure 3 - Spatial arrangement x planting date interaction effect on 100-seed weight. Vertical bars represent \pm 1 SE of means.

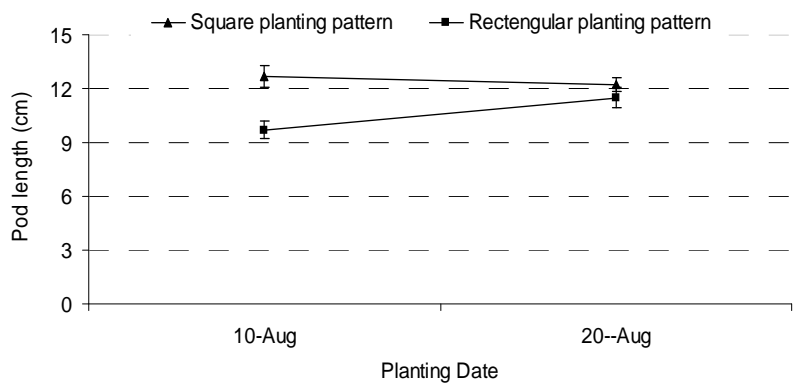

Figure 4 - Spatial arrangement x planting date interaction effect on pod length. Vertical bars represent \pm 1 SE of means.

In conclusion, this experiment illustrated that plants in a square planting arrangement produced significantly greater seed yield compared to those in a rectangular planting pattern. In the rectangular arrangement, due to weed competition, seed and pod yields were reduced by $11.6 \%$ and $7.6 \%$, respectively. Based on the results of this study, weed control, as well as square planting pattern, are recommended for obtaining the highest seed and pod yields in common bean.

\section{LITERATURE CITED}

ACCIARESI, H. A.; CHIDICHIMO, H. O. Spatial pattern effect on corn (Zea mays) weed competition in the humid Pampas of Argentina. Inter. J. Pest Manage., v. 53, n. 1, p. 195-206, 2007.

ACCIARESI, H. A.; ZULUAGA, M. S. Effect of plant row spacing and herbicide use on weed aboveground biomass and corn grain yield. Planta Daninha, v. 24, n. 2, p. 287-293, 2006.

AGUYOH, J. N.; MASIUNAS, J. B. Interference of redroot pigweed (Amaranthus retroflexus) with snap beans.

Weed Sci., v. 51, n. 2, p. 202-207, 2003.

AKTER, R. et al. Effect of weeding on the growth, yield and yield contributing characters of mungbean (Vigna radiata L.). J. Bangladesh Agric. Univ., v. 11, n. 1, p. 53-60, 2013.

BADOWIEC, A.; WEIDNER, S. Proteomic changes in the roots of germinating Phaseolus vulgaris seeds in response to chilling stress and post-stress recovery. J. Plant Physiol., v. 171, n. 6, p. 389-398, 2014.

BHARDWAJ, H. L. et al. White lupin performance and nutritional value as affected by planting date and row spacing. Agron. J., v. 96, n. 2, p. 580-583, 2004.

BLACKSHAW, R. E. Hairy nightshade (Solanum sarrachoides) interference in dry beans (Phaseolus vulgaris). Weed Sci., v. 39, n. 1, p. 48-53, 1991.

BLACKSHAW, R. E. et al. Canopy architecture, row spacing and plant density effects on yield of dry bean (Phaseolus vulgaris) in the absence and presence of hairy nightshade (Solanum sarrachoides). Can. J. Plant Sci., v. 79, n. 4, p. 663-669, 1999.

BURUCHARA, R. et al. Development and Delivery of bean varieties in africa: the Pan-Africa bean research Alliance (PABRA) model. Afr. Crop Sci. J., v. 19, n. 4, p. 227-245, 2011.

DARBY, H. M.; LAUER, J. G. Harvest date and hybrid influence on corn forage yield, quality, and preservation. Agron. J., v. 95, n. 3, p. 559-566, 2002. 
DE BRUIN, J. L., et al. Soybean photosynthetic rate and carbon fixation at early and late planting dates. Crop Sci., v. 50, n. 6, p. 2516-2524, 2010.

DUSABUMUREMYI, P. et al. Narrow row planting increases yield and suppresses weeds in common bean (Phaseolus vulgaris L.) in a semi-arid agro-ecology of Nyagatare, Rwanda. Crop Protect., v. 64, n. 1, p. 13-18, 2014.

FANADZO, M. et al. Narrow rows and high maize densities reduce maize grain yield but suppress weeds under dryland conditions in Zimbabwe. J. Agron., v. 6, n. 4, p. 566-570, 2007.

FOOD AND AGRICULTURAL ORGANIZATION - FAO. FAOSTAT statistics database [Online]. < Available at http:// http://faostat.fao.org> 2014.

HILL, J. E. et al. Rice weeds control: current technology and emerging issues in the United States. In: TEMPERATE RICE CONFERENCE, 1994, Yanco, New South Wales, Australia, 21-24 February. Proceedings... Yanco: 1994. p. 377-391.

HOLMES, R. C.; SPRAGUE, C. L. Row width affects weed management in type II black bean. Weed Technol., v. 27, n. 3, p. 538-546, 2013.

HOSSAIN, I. et al. Planting date influence on dual-purpose winter wheat forage yield, grain yield, and test weight.

Agron. J., v. 95, n. 5, p. 1179-1188, 2003.

MALIK, V. S. et al. Interaction of white bean (Phaseolus vulgaris L.) cultivars, row spacing and seeding density with annual weeds. Weed Sci., v. 41, n. 1, p. 62-68, 1993.

MASHINGAIDZE, A. B. et al. Narrow rows reduce biomass and seed production of weeds and increase maize yield. Ann. Appl. Biol., v. 155, n. 2, p. 207-218, 2009.

OLSEN, J.; WEINER, J. The influence of Triticum aestivum density, sowing pattern and nitrogen fertilization on leaf area index and its spatial variation. Basic Appl. Ecol., v. 8, n. 3, p. 252-257, 2007.

OLSEN, J. M. et al. How important are crop spatial pattern and density for weed suppression by spring wheat?

Weed Sci., v. 60, n. 3, p. 501-509, 2012.

OLSEN, J.; WEINER, J. Effects of density and spatial pattern of winter wheat on suppression of different weed species. Weed Sci., v. 53, n. 5, p. 690-694, 2005.
PYNENBURG, G. M. et al. The interaction of annual weed and white mold management systems for dry bean production in Canada. Can. J. Plant Sci., v. 91, n. 3, p. 587-598, 2011.

RAO, A. N. et al. Weed management in direct seeded rice. Adv. Agron., v. 93,n. 1, p. 153-255, 2007.

SAS. SAS Version 9.1. Cary: SAS Institute, 2004.

SCHWARTE, A. J. et al. Planting date effects on winter triticale dry matter and nitrogen accumulation. Agron. J., v. 97, n. 5, p. 1333-1341, 2005.

SRINIVASAN, A. et al. Cold tolerance during early reproductive growth of chickpea (Cicer arietinum L.): genetic variation in gamete development and function. Field Crops Res., v. 60, n. 2, p. 209-222, 1999.

TEASDALE, J. R. Influence of narrow row/high population corn (Zea mays) on weed control and light transmittance. Weed Technol., v. 9, n. 1, p. 113-118, 1995.

VANCE, C. P. Root-bacteria interactions: symbiotic nitrogen fixation. In: WAISEL, Y; ESHEL, A.; KAFKATI, U. (Ed.)

Plant roots: The Hidden Half, Ed 3. New York: Marcel Dekker, 2002. p. 839-867.

VOGT, G. A. et al. Competitive ability of black common bean genotypes with weeds. Ci. Agrotec., v. 37, n. 5, p. 397-403, 2013.

WEINER, J. et al. Evolutionary Agroecology: the potential for cooperative, high density, weed-suppressing cereals. Evol. Appl., v. 3, n. 5/6, p. 473-479, 2010.

WEINER, J. et al. Suppression of weeds by spring wheat (Triticum aestivum) increases with crop density and spatial uniformity. J. Appl. Ecol., v. 38, n. 4, p. 784-790, 2001.

WESTGATE, M. E. et al. Rapid canopy closure for maize production in the northern US Corn Belt: radiation use efficiency and grain yield. Field Crops Res., v. 49, n. 2/3, p. 249-258, 1997.

WIDERS, I. E. The beans for health alliance: a public-private sector partnershipto support research on the nutritional and health attributes of beans. Ann. Rep. Bean Improv. Coop., v. 49, n. 1, p. 3-5, 2006.

WOOLLEY, B. L. et al. The critical period of weed control in white bean (Phaseolus vulgaris). Weed Sci., v. 41, n. 2, p. 180-184, 1993. 